\title{
Gut glucagon-like immunoreactants (GLIs) and other enteric glucagon-like peptides
}

\author{
A. J. MOODY
}

From the Novo Research Institute, Novo Allé, DK-2880 Bagsvaerd, Denmark

The term glucagon was coined by Kimball and Murlin (1923) to describe a hyperglycaemic substance which they had partially purified from an extract of bovine pancreas. In 1953, Staub et al. crystallised a pancreatic hyperglycaemic glycogenolytic factor (HGF), for which they accepted the name glucagon in 1955 (Staub et al., 1955). The amino-acid sequence of porcine glucagon was published in 1956 by Bromer et al. With the exception of guinea pig glucagon, all mammalian glucagons so far isolated have the same 29 amino-acid sequence as porcine glucagon (Sundby, 1976). Avian glucagons differ from porcine glucagon; for example turkey glucagon differs by having a serine residue at position 28 instead of asparagine, and duck glucagon by also having a threonine at position 16 instead of serine (Fig. 1). In the mammals studied so far, glucagon has been located mainly in the pancreas, where it is synthesised in the A cells of the islets of Langerhans (Bussolati et al., 1971). A well characterised gastric glucagon has, however, been located in A-like cells in the canine gastric mucosa (Vranic et al., 1976).

The first description of a substance in the gastrointestinal tract with glucagon-like activities was the demonstration by Sutherland and de Duve (1948) of a hyperglycaemic-glycogenolytic factor in the canine upper gastrointestinal tract. This presentation summarises our knowledge of those glucagonlike peptides which have been isolated from enteric tissues since this first report.

Enteric peptides can be considered to be glucagonlike if (1) they have chemical similarities to glucagon (secretin, VIP, GIP, and gut GLIs); (2) they exert biological effects similar to those of glucagon (secretin, VIP, GIP, and gut GLIs); or (3) they have an immunoreactant in common with glucagon (gut GLIs). The extensive similarities between the sequences of glucagon, VIP, secretin, and GIP have been discussed elsewhere in these proceedings. The four peptides have very similar spectra of biological effects: secretin, glucagon, and VIP stimulate lipolysis, VIP and glucagon activate glycogenolysis, and all of the peptides are insulin-releasing in one system or another (see Marks and Turner, 1977 for a review). These effects are probably all exerted via stimulation of adenyl cyclase but involve binding of the peptides to separate receptors on the cell surface The physiology of secretin, VIP, and GIP is describee elsewhere in these proceedings so the remainder of this section is restricted to the gut glucagon-like immunoreactants (gut GLIs).

\section{Gut glucagon-like immunoreactants}

The term gut glucagon-like immunoreactant is used for any gut peptide which reacts with an antiglucagon serum to prevent the binding of radioiodinated glucagon to the antibodies in the serum. The existence of gut GLIs and the pattern of their secretion by the intestine was shown in the 1960s, largely by Unger and co-workers (1968). They react with only one type of anti-glucagon serum, variously known as non-specific, cross-reacting, or $\mathbf{N}$ terminal specific (see immunochemistry below).

Long-chain triglycerides and glucose have been shown to release gut GLIs, as has the ingestion of mixed meals (see Bloom and Polak, 1977 for a O review). Plasma levels of gut GLI after an oral load are above normal in subjects in whom the absorption of focdstuffs by the upper small intestine is reduced, either by malabsorption such as is found in coeliac

\begin{tabular}{|c|c|c|c|c|c|c|c|c|c|c|c|c|c|}
\hline \multicolumn{14}{|c|}{ Sequences of immunoreactive sites } \\
\hline & $1 \ldots$ & .....11 & 12 & $\mathfrak{B}$ & $k$ & 15 & $16 \ldots$ & .24 & 25 & 26 & 27 & 28 & 29 \\
\hline Porcine glucagon & His & Ser & Lys & Tyr & Leu & Asp & Ser & Gln & Trp & Leu & Met & Asn & Thr \\
\hline Duck glucagon & & & & & & & Thr & & & & & Ser & \\
\hline Turkey glucagon & & & & & & & & & & & & Ser & \\
\hline
\end{tabular}

Fig. 1 The amino-acid sequences of the possible immunoreactive sites of glucagon. The differences between duck and turkey glucagons (Sundby, 1976) and porcine glucagon (Bromer et al., 1956) are also shown. 
disease, or as a consequence of the surgical removal of the upper small intestine (see Besterman, page 76).

Gut GLIs are found in the intestinal L cell, which is located in the intestinal mucosa and which differs from the pancreatic A cell (Orci et al., 1968). The L cell is found throughout the small intestine and is particularly frequent in the lower small intestine and colon. This distribution of the $L$ cell is in agreement with the distribution of gut GLIs in extracts of the different sections of the intestinal tract (Bloom and Polak, 1978).

\section{SIZE}

Gut GLIs extracted from the intestine can be separated into two classes by gel permeation chromatography, with approximate molecular weights of 6000 and 4000, respectively (Valverde et al., 1970). Circulating gut GLIs have a similar size distribution. The extracted gut GLIs can be further fractionated, particularly by isoelectric focusing (Moody et al., 1975). The plurality of gut GLIs that can be demonstrated is probably the result of modifications occurring during extraction and fractionation, and does not reflect the forms found in vivo.

\section{BIOLOGICAL EFFECTS}

No biologically active highly purified gut GLI has so far been described. Crude duck gut GLI with a molecular weight of 6000 to 13000 was found to inhibit the glucagon-induced lipolysis of duck adipocytes (Krug and Mialhe, 1977). Partially purified porcine gut GLI with a molecular weight of approximately 4000 has been found to inhibit the binding of ${ }^{125} \mathrm{I}$-glucagon to liver plasma membranes, to stimulate liver plasma membrane adenyl cyclase (Bataille et al., 1974; Moody et al., 1975), and also to stimulate insulin release (Tanaka et al., 1977). With the exception of the displacement of ${ }^{125} \mathrm{I}$ glucagon from liver plasma membranes, these effects could well have been caused by a contaminating peptide such as VIP.

\section{IMMUNOCHEMISTRY}

The detailed structures of gut GLIs are, as yet, unknown but a consideration of the immunochemistry of glucagon provides a background for their study. It was appreciated early in the development of the radioimmunoassay for glucagon that the peptide is a poor antigen and that most antiglucagon sera bound not only glucagon but also gut GLIs (Heding, 1972). Assan and Slusher (1972) pointed out that the antisera which react with both gut GLIs and glucagon are directed towards the $\mathrm{N}$ terminal and central portions of the glucagon molecule. In contrast, the antisera which react with glucagon alone react with the $\mathrm{C}$ terminal portion of the glucagon molecule. This description of two antigenic sites in the glucagon molecule has now been extended. Heding et al. (1976) found that duck glucagon and glucagon modified at position 27 react very poorly with antiglucagon sera directed towards the $\mathrm{C}$ terminal portion of the molecule, and proposed that the $\mathrm{C}$ terminal antigenic site of glucagon involves positions 24 to 29 . A probable location of the $\mathrm{N}$ terminal antigenic site, which Assan and Slusher (1972) suggested as being in the region 9 to 23 and Heding et al. (1976) in the region 2 to 23, has recently been defined as follows. It was suggested (Moody et al., 1978) that the $\mathrm{N}$ terminal antigenic site was in the glucagon sequence 11 to 14 , because that is the only extensive part of the glucagon sequence which is not found in secretin, VIP, or GIP which does not react with antiglucagon sera. Yanaihara et al. (1979), on the basis of studies with synthetic fragments of glucagon, has proposed that the $\mathbf{N}$ terminal immunoreactive site in glucagon is located in the sequence 1 to 16 . Duck glucagon, with a threonine instead of serine at position 16 , has much the same immunoreactivity with $\mathbf{N}$ terminal specific antiglucagon sera as porcine glucagon and turkey glucagon. The antiglucagon sera that react with glucagon, avian glucagons, and gut GLIs therefore probably react with the glucagon sequence 11 to 15 , whereas the antiglucagon sera that react with mammalian glucagons react with the glucagon sequence 24 to 29 . The amino-acid sequences involved in these proposed immunoreactants are shown in Fig. 1.

Glucagon coupled to albumin with glutaraldehyde evokes the formation of a very high percentage of antiglucagon (24 to 29) sera (Garaud et al., 1976). Since glutaraldehyde probably reacts with the lysine residue at position 12 , thereby disrupting the structure of glucagon in this region, this finding provides indirect support for the proposal that glucagon has an antigenic site in the region 11 to 15 .

The detection of gut GLIs with an antiglucagon (11 to 15 ) serum shows that the sample contains a peptide or peptides with an immunoreactive site similar to that of glucagon (11 to 15), but it does not provide any information about the structure of the molecule outside the immunoreactant.

It is of particular interest to know whether the gut GLIs have in common with glucagon only an immunoreactive site corresponding to the glucagon sequence 11 to 15 or whether they have an extensive chemical similarity to glucagon.

\section{STR UCT URE}

The isolation of a porcine protein, gut GLI-1 (also known as glicentin), with full immunoreactivity with antiglucagon (11 to 15$)$ sera, but devoid of 


$\begin{array}{ll} & 27 \quad 28 \quad 29 \\ \text { Glucagon } & \text { Met-Asn-Thr } \\ \text { Pro-glucagon } & \text { Met-Asn-Thr-Lys-Arg-Asn-Asn-Lys-Asn-Ile-Ala } \\ \text { Glicentin } & \text { Met-Asn-Thr-Lys-Arg-Asn-Lys-Asn-Asn-Ile-Ala }\end{array}$

Fig. 2 The 3 amino-acids from the $C$ terminus of glucagon (Bromer et al., 1956) are aligned with the partial $C$ terminal sequences of a proglucagon fragment (Tager and Steiner, 1973) and of porcine glicentin (Jacobsen et al., 1977). The difference between the latter two sequences is underlined. reactivity with antiglucagon (24 to 29 ) sera, has provided us with the opportunity to study in detail the relationship of a gut GLI to glucagon.

Glicentin contains 100 amino-acids, including all of those found in porcine glucagon (Sundby et al., 1976). The eleven residues from the $C$ terminal end consist of the three $\mathrm{C}$ terminal amino-acids of glucagon with an octapeptide attached to the C terminal threonine (Jacobsen et al., 1977). The same eight amino-acids were also described in the $\mathrm{C}$ terminal octapeptide of a proposed proglucagon fragment by Tager and Steiner (1973). The C terminal sequences of glicentin and this proglucagon fragment are shown in Fig. 2. The two sequences are closely related, the only difference being an inversion of the lysine and arginine at positions 3 and 4 from the $\mathbf{C}$ terminal alanine of glicentin. Further sequence studies have supported the concept that glicentin contains the full sequence of glucagon, placed so that the 37 amino-acids from the $\mathrm{C}$ terminal end of glicentin consist of glucagon prolonged by the octapeptide shown in Fig. 2. If the proposed structure is correct, then gut GLIs smaller than glicentin will be found to consist of the sequence of glucagon modified by $\mathrm{N}$ and $\mathrm{C}$ terminal additions or deletions.

It has been proposed (Moody et al., 1978) that the C terminal octapeptide in some way 'masked' the immunoreactant present in the sequence corresponding to the glucagon sequence 24 to 29 , leaving glicentin only one immunoreactive site in common with glucagon, corresponding to glucagon 11 to 15 . Proof of this postulate has been provided by Yanaihara et al. (1979), who synthesised glucagon (17 to 29) attached to the C terminal octapeptide of glicentin, and glucagon ( 23 to 29 ) attached to the $\mathrm{C}$ terminal octapeptide of the proglucagon fragment of Tager and Steiner (1973). Neither of these peptides reacted with an antiglucagon (24 to 29) serum, but synthetic glucagon (19 to 29$)$ had $31 \%$ molar immunoreactivity with this antiserum.

Highly purified glicentin coupled to albumin with glutaraldehyde was used to raise antiglicentin sera in rabbits. One of these sera, R64, which does not bind glucagon has been used for immunocytochemical studies of the distribution of glicentin, using indirect immunofluorescence and peroxidase techniques. R64 binds to the secretory granules in the $\overrightarrow{\vec{\omega}}$ pancreatic A cell and the intestinal $L$ cell in several $\stackrel{\circ}{\rightarrow}$ species (Ravazzola et al., 1979). These observations have been confirmed by the detection of immuno- is reactive glicentin in pancreatic extracts (Moody et al., 1978). The immunocytochemical and radioimmuno- $\overrightarrow{-}$ logical evidence led us to propose that a glicentin- $\infty$ like peptide is a glucagon precursor, and that the initial genetically determined product in both $\mathbf{A}$ and $\mathrm{L}$ cells is a glicentin-like molecule which is cleaved to glucagon in the A cell and to smaller gut GLIs in the L cell (Moody et al., 1978).

Quantitative estimation of the immunoreactive $\vec{C}$ (IR) glicentin content of rat and human pancreas, and of a single glucagonoma were disappointing. 9 was found that the IR glicentin was only one part per: thousand of the total GLI, although in all cases immunoreactive glicentin was found to have $\vec{a} \bar{o}$ similar size to ${ }^{125} \mathrm{I}$-glicentin by gel filtration on $\%$ Sephadex G50. These very low levels were at variance $\stackrel{\varnothing}{\varnothing}$ with the intense immunocytochemical staining of the $\overrightarrow{\overrightarrow{0}}$ A cell by R64. It is possible that antibodies with 3 different specificities were involved in the immunocytochemical and immunochemical reactions. Alter-? natively, the fixation techniques used in the immunocytochemical studies could have enhanced the immunoreactivity of small amounts of glicentin.

Initial studies of IR glicentin in human plasma led us to believe that it could be detected, and that levels 3 rose after an oral glucose load provided that the gut $\circ$ GLI rose to above $300 \mathrm{pmol} / \mathrm{l}$. More recent studies with an improved assay have failed to support these findings, and we do not think at present that the radioimmunoassay for porcine glicentin can detect $\widetilde{N}$ substantial amounts of immunoreactive glicentin in N human plasma from peripheral veins.

In the pig, fasting levels of $95 \mathrm{pmol} / 1$ have been measured, which increase significantly after feeding and remain raised for up to 3 hours or more after feeding (Table).

These findings suggest that a peptide containing one of the immunoreactive sites of glicentin is released by the porcine $L$ cell after feeding. Further $\mathbb{D}$ investigation is required to establish whether IR $\frac{?}{\mathbb{D}}$ glicentin is associated with intact glicentin or with $a \frac{\square}{2}$
small peptide. 


\begin{tabular}{|c|c|c|c|c|}
\hline & \multicolumn{4}{|c|}{ Mean plasma immunoreactive glicentin (pmol/l) } \\
\hline & \multirow[t]{2}{*}{ Fasting } & \multicolumn{3}{|c|}{ After feeding } \\
\hline & & $1 \mathrm{~h}$ & $2 h$ & $3 h$ \\
\hline \multirow{2}{*}{$\begin{array}{l}\text { Group I } \\
(n=8) \\
\text { Group II } \\
(n=2)\end{array}$} & 95 & $135^{*}$ & - & - \\
\hline & 98 & 126 & 164 & 160 \\
\hline
\end{tabular}

*Significantly different from the fasting level $(P<0.01)$.

Studies carried out in pigs after overnight fast. Food was allowed immediately after the first sample.

Table The effect of feeding on plasma glicentin

\section{Conclusion}

The enteric glucagon-like peptides share to a varying degree the chemical, biological, and immunochemical characteristics of glucagon. Despite the overlap of the biological effects of these peptides, particularly in vitro, they probably have relatively specific effects in vivo. This specificity of action occurs because the peptides are released from their site of origin by specific stimuli, and because the receptors for the individual peptides are restricted to a limited number of types of cell.

The gut GLIs probably consist of an amino-acid sequence basically identical with that of glucagon but modified by extension or shortening of the $\mathrm{C}$ and $\mathrm{N}$ terminal ends. This proposed structure of the gut GLIs explains why they react with antisera to glucagon (11 to 15$)$ and why gut GLIs with a size similar to that of glucagon exert glucagon-like biological effects. The gut GLIs are therefore the most glucagon-like of all the peptides discussed here. The proposed structure does not, however, provide information about the role of endogenous gut GLIs. It has been proposed that gut GLIs control the growth and function of the upper small intestine (Bloom and Polak, 1977) but proof of this proposal awaits the isolation and characterisation of biologically active gut GLIs.

Karin Damm Jørgensen kindly carried out the experiments summarised in the Table. The technical assistance of E. Mortensen is gratefully acknowledged.

\section{References}

Assan, R., and Slusher, N. (1972). Structure/function and structure/immunoreactivity relationships of the glucagon molecule and related synthetic peptides. Diabetes, 21, 843-855.

Bataille, D., Freychet, P., and Rosselin, G. (1974). Interactions of glucagon, gut glucagon, VIP and secretin with liver and fat cell plasma membranes: binding to specific sites and stimulation of adenylate cyclase. Endocrinology, 95, 713-721.
Bloom, S. R., and Polak, J. M. (1977). The new peptide hormones of the gut. In Progress in Gastroenterology, Vol. III, pp. 109-151, ed G. B. Jerzy Glass. Grune and Stratton, New York.

Bloom, S. R., and Polak, J. M. (1978). Gut hormone overview. In Gut Hormones, pp. 3-18, ed S. R. Bloom. Churchill Livingstone, Edinburgh.

Bromer, N. W., Sinn, L. G., Staub, A., and Behrens, O. K. (1956). The amino acid sequence of glucagon. Journal of the American Chemical Society, 78, 3858-3860.

Bussolati, G., Capella, C., Vassallo, G., and Solcia, E. (1971). Histochemical and ultrastructural studies on pancreatic A cells: evidence for glucagon and nonglucagon components of the $\alpha$ granule. Diabetologia, 7, 181-188.

Garaud, J. C., Moody, A. J., Eloy, R., and Grenier, J. F. (1976). Unusual specificities of antibodies to glucagonglutaraldehyde-albumin conjugates. Hormone and Metabolic Research, 8, 241-243.

Heding, L. G. (1972). Immunologic properties of pancreatic glucagon: antigenicity and antibody characteristics. In Glugacon: Molecular Physiology, Clinical and Therapeutic Implications, pp. 187-200, ed P. J. Lefebvre and R. H. Unger. Pergamon Press, Oxford.

Heding, L. G., Frandsen, E. K., and Jacobsen, H. (1976). (Glugacon). Structure-function relationship: immunologic. Metabolism, 25, 1327-1329.

Jacobsen, H., Demandt, A., Moody, A. J., and Sundby, F. (1977). Sequence analysis of porcine gut GLI-1. Biochimica et Biophysica Acta, 493, 452-459.

Kimball, C. P., and Murlin, J. R. (1923). Aqueous extracts of pancreas. III. Some precipitation reactions of insulin. Journal of Biological Chemistry, 58, 337-346.

Krug, E., and Mialhe, P. (1977). A possible role for gut GLI: an inhibitor of lipolysis. Hormone and Metabolic Research, 6, 465-469.

Marks, V., and Turner, D. S. (1977). The gastricintestinal hormones with particular reference to their role in the regulation of insulin secretion. Essays in Medical Biochemistry, 3, 109-152.

Moody, A. J., Frandsen, E. K., and Sundby, F. (1975). Fractionation of gut glucagon-like activities by isoelectric focusing in polyacrylamide gel. In Progress in Isoelectric Focusing and Isotachophoresis, pp. 179-191, ed P. G. Righetti. North Holland, Amsterdam.

Moody, A. J., Jacobsen, H., and Sundby, F. (1978). Gastric glucagon and gut glucagon-like immunoreactants. In Gut Hormones, pp. 369-378, ed S. R. Bloom. Churchill Livingstone, Edinburgh.

Orci, L., Pictet, R., Forssmann, W. G., Renold, A. E., and Rouiller, C. (1968). Structural evidence for glucagon producing cells in the intestinal mucosa of the rat. Diabetologia, 4, 56-67.

Ravazzola, M., Siperstein, A., Moody, A. J., Sundby, F., Jacobsen, H., and Orci, L. (1979). Glicentin immunoreactive cells: their relationship to glucagon producing cells. Endocrinology, 105, 499-508.

Staub, A., Sinn, L., and Behrens, O. K. (1953). Purification and crystallisation of hyperglycemic glycogenolytic factor. Science, 117, 628-629. 
Staub, A., Sinn, L., and Behrens, O. K. (1955). Purification and crystallisation of glucagon. Journal of Biological Chemistry, 214, 619-632.

Sundby, F. (1976). Species variation in the primary structure of glucagon. Metabolism, 25, 1319-1321.

Sundby, F., Jacobsen, H., and Moody, A. J. (1976). Purification and characterisation of a protein from porcine gut with glucagon-like immunoreactivity. Hormone and Metabolic Research, 8, 366-371.

Sutherland, E. W., and de Duve, C. (1948). Origin and distribution of the hyperglycemic-glycogenolytic factor of the pancreas. Journal of Biological Chemistry, 175, 663-674.

Tager, H. S., and Steiner, D. F. (1973). Isolation of a glucagon-containing peptide: primary structure of a possible fragment of proglucagon. Proceedings of the National Academy of Sciences of the USA, 70, 23212325.

Tanaka, R., Matsuyama, T., Shima, K., Sawazaki, N.,
Tarui, S., and Kumahara, Y. (1977). Insulin releasing activity of gastrointestinal glucagon-like immuno- $\vec{F}$ reactive materials in perfused rat pancreas. Endocrinologia Japonica, 24, 575-579.

Unger, R. H., Ohneda, A., Valverde, I., Eisentraut, A. M., 흘 and Exton, J. (1968). Characterisation of the responses $\frac{\bar{s}}{\partial}$ of circulating glucagon-like immunoreactivity to $\frac{\mathbb{}}{\circ}$ intraduodenal and intravenous administration of glucose. Journal of Clinical Investigation, 47, 48-65.

Valverde, I., Rigopoulou, D., Marco, J., Faloona, G. R., $\vec{\circ}$ and Unger, R. H. (1970). Characterisation of glucagon like immunoreactivity (GLI). Diabetes, 19, 614-623.

Vranic, M., Engerman, R., Doi, K., Morita, S., and $\frac{2}{2}$ Yip, C. C. (1976). Extrapancreatic glucagon in the dog. Metabolism 25, 1469-1473.

Yanaihara, N., Yanaihara, C., Nishida, T., Hiraiwa, T., $\dot{1}^{\circ}$ Mihara, S., Sakagami, M., Ozaki, J., Imagawa, K., and Shin, S. (1979). Hormone Receptors in Digestion and Nutrition, pp. 65-68, ed G. Rosselin, P. Fromageot, 0 and S. Bonfils. Elsevier/North Holland, Amsterdam. 